Aleksandra Jaśniewicz

(Dublin)

https://orcid.org/0000-0001-5639-4422

\title{
Model do medalu Daniela Placotomusa w kontekście medali osobistych w szesnastowiecznym Gdańsku
}

DOI: https://doi.org/10.26881/porta.2019.18.03

Renesansowe medale portretowe stanowią doskonałą realizację nurtującej ówczesnego człowieka potrzeby utrwalenia i multiplikacji własnego wizerunku. Formuła medalu osobistego, która wypracowana została w 1438 r. przez Antonia Pisanella, wyrasta $\mathrm{z}$ fascynacji klasycznymi wizerunkami władców starożytności widniejącymi na monetach i kameach ${ }^{1}$. Nowożytne medale osobiste, sporządzane zazwyczaj w niewielkiej liczbie egzemplarzy, powstawały z przeznaczeniem dla ograniczonej liczby odbiorców i często przekazywane były jako podarunki.

Już w latach sześćdziesiątych XV w. ta forma upamiętnienia była znana na terenie Rzeszy, jednak dopiero po pierwszej dekadzie kolejnego stulecia upowszechniła się w krajach niemieckich ${ }^{2}$. Zapotrzebowanie na medale dość szybko objęło swoim zasięgiem szerokie kręgi niemieckiego społeczeństwa: przedstawicieli władzy, uczonych, mieszczan i kupców ${ }^{3}$. W latach dwudziestych XVI w. medale osobiste zaczęli zamawiać gdańszczanie. Przedmiotem debaty pozostaje kwestia, czy wpływ na zainteresowanie portretami medalierskimi miała wizyta wybitnego medaliera-portrecisty Hansa Schwarza w Gdańsku Szesnastowieczne medale upamiętniające przedstawicieli gdańskiego mieszczaństwa zamawiano w znakomitej większości podczas naukowych peregrynacji,

1 Jako że medale osobiste były pozbawione aspektu merkantylnego, panowała dowolność $\mathrm{w}$ wyborze materiału, $\mathrm{z}$ jakiego były wykonywane, zob. Stephen K. Scher, Introduction [w:] The currency of fame. Portrait Medals of the Renaissance, ed. Stephen K. Scher, New York 1994, s. 13-16; Thomas W. Greene, Renaissance medals in relation to antique gems and coins, „The Numismatic Chronicle and Journal of the Numismatic Society" 1885, vol. 5, s. 73.

2 Scher, Introduction..., s. 23.

3 Lore Börner, Deutsche Medaillenkleinode des 16. und 17. Jahrhunderts, Leipzig 1981, s. 8.

4 Pokłosiem jego pobytu w Gdańsku wiosną 1526 r. jest pięć lub sześć medali upamiętniających Zygmunta Starego, zob. Adam Więcek, Dzieje sztuki medalierskiej w Polsce, Kraków 1989, s. 14; Maria Stahr, Medalierstwo [w:] Aurea Porta Rzeczypospolitej. Sztuka gdańska od połowy XV do końca XVIII wieku, t. 1. Eseje, Gdańsk 1997, s. 157; Karol Nowaliński, Medalierstwo gdańskie XVI-XVIII wieku, „Przegląd Numizmatyczny” 1997, t. 19, nr 4, s. 6. Na temat sztuki medalierskiej na dworze Zygmunta Starego por. Mieczysław Morka, The beginnings of Medallic Art in Poland during the Times of Zygmunt I and Bona Sforza, „Artibus et Historiae” 2008, vol. 29, No. 58, s. 65-87. 
podróży handlowych czy dyplomatycznych. Wykonywano je w przodujących w produkcji medalierskiej warsztatach norymberskich i augsburskich, ośrodkach mniej znaczących, jak Praga czy Wiedeń, na terenie wschodniej Brandenburgii i Prus oraz w trudnych czasem do określenia warsztatach prowincjonalnych ${ }^{5}$.

Historię medali osobistych związanych z Gdańskiem otwiera zaginiony, wykonany w 1522 r. w Anglii, medal upamiętniający Jana Dantyszka. Kolejne medale dyplomaty, od 1531 r. biskupa warmińskiego, powstały w Niderlandach: to dwa obiekty z 1529 r. (medal i bukszpanowy model ${ }^{6}$ ), medal z 1531 r., wszystkie wykonane przez Christopha Weiditza, oraz medal autorstwa Johanna Secundusa z 1532 r. ${ }^{7} \mathrm{Na}$ przestrzeni XVI w. na zamówienie mieszkańców Gdańska powstały trzy, odnotowane w dotychczasowej literaturze, modele medalierskie i siedem medali: bukszpanowy model do medalu Georga Schewecke (Jacob Binck [?], 1544), kamienne modele do medali Hansa Klura (Hans Schenck zw. Scheusslich, 1546) i Jacoba Connerta (Mistrz Jerzego Fryderyka Brandenburskiego [?], 1599 [?]); srebrne medale upamiętniające Johanna I Connerta (1556, antydatowany na rok 1456, Jacob Stampfer [?]) i Johanna IV Connerta (1557), Marcusa Koehne-Jaschkego (Hans Wild, 1561 i 1562), Cathariny Placotomi (Joachim Deschler [?], 1568), Jacoba Schachmanna (Severin Brachmann [?], 1570) oraz heraldyczny medal Hansa Schwarzwaldta $(1575)^{8}$. O skali zainteresowania nad Motławą tą formą upamiętnienia świadczy fakt, że w XVI w. - w świetle znanego w literaturze materiału - powstało niemalże tyle medali osobistych, ile świeckich portretów malarskich.

Powyższe zestawienie należy uzupełnić o nieznany dotąd model do medalu upamiętniającego Daniela Placotomusa (około 1566-1616, il. 1). Ten wykonany $\mathrm{w}$ wapieniu $\mathrm{z}$ Solnhofen obiekt pojawił się na rynku antykwarycznym w 2003 r., określony wówczas jako sporządzony w Augsburgu model do medalu

5 Na temat gdańskich medali osobistych por. Georg Habich, Die Deutschen Schaumünzen des XVI Jahrhunderts, München 1924-1932; Siegfried Rühle, Die Danziger Personenmedaillen, „Zeitschrift des Westpreussischen Geschichtsvereins" 1930, Bd. 70, s. 141-175; Stahr, Medalierstwo..., s. 157-159; Jarosław Dutkowski, Motywy idei mieszczańskich na monetach, medalach i żetonach gdańskich od końca XVI do połowy XVIII wieku w Gdańsku, praca doktorska napisana na UG pod kierunkiem prof. dr. hab. Krzysztofa M. Kowalskiego, Gdańsk 2007. Za pomoc w uzyskaniu dostępu do pracy dziękuję dr Magdalenie Mielnik.

6 Odlewy z tego modelu nie są znane. Jego autorstwo bywa łączone z osobą Macieja Schillinga, medaliera i rytownika stempli, por. Dutkowski, Motywy idei..., s. 228.

7 Marian Gumowski, Jan Dantyszek i jego medale, „Zapiski Towarzystwa Naukowego w Toruniu" 1929, nr 17, s. 5-17.

8 Większość z nich, obecnie zaginiona, do czasów drugiej wojny światowej znajdowała się w zbiorach Miejskiego Gabinetu Numizmatycznego (Danziger Munzkabinett) przy Gimnazjum Miejskim (model do medalu Jacoba Connerta, srebrne medale upamiętniające Johanna i Hansa Connertów, medale Marcusa Koehne-Jaschkego, Cathariny Placotomi, Jacoba Schachmanna oraz Hansa Schwarzwaldta). W analogicznym zestawieniu Maria Stahr wymienia także bukszpanowy model do medalu Georga Schewecke, przy czym obiekt ten należał przed drugą wojną światową do zbiorów Stadtmuseum (obecnie znajduje się w Muzeum Narodowym w Gdańsku), por. Stahr, Medalierstwo..., s. 157.

Model do medalu Daniela Placotomusa... 
Aleksandra upamiętniającego rzeźbiarza lub kamieniarza Daniela9 . Popiersiowa podobizna, Jaśniewicz starannie wkomponowana w pole wyznaczone przez majuskułową inskrypcję „DANIEL PLACTOCOMVS DANTISCA: AETA: 28”, została wykonana w płytkim reliefie, z wyraźną dbałością o drobiazgowe oddanie szczegółów fizjonomii: wnikliwie opracowanej partii krótko przyciętych włosów z uniesionym nad czołem lokiem, zarostu, zdecydowanego profilu o wysuniętej dolnej szczęce, wreszcie

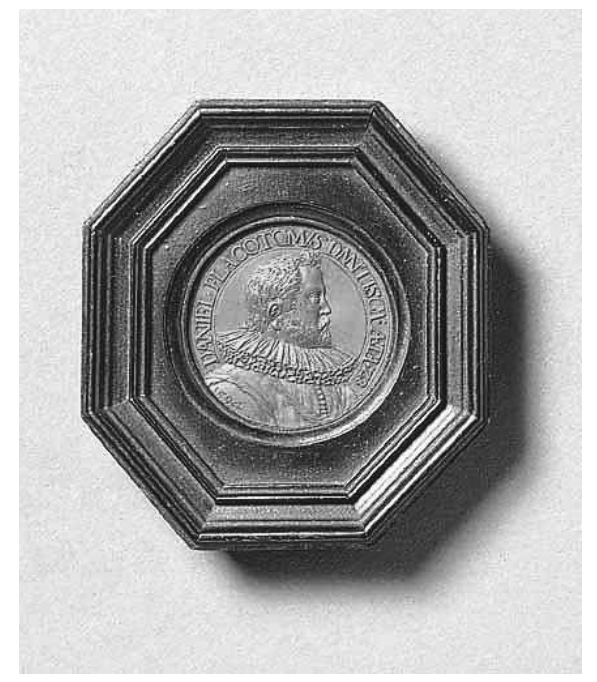

Il. 1. Medalier nieznany, kamienny model do medalu Daniela Placotomusa, 1594, zbiory prywatne, fot. http://search.sothebys. com/jps/live/lot/LotDetail.jsp?lot_id=45P6B szramy biegnącej poprzecznie od kości policzkowej do ucha. Dokładnie odtworzono także strój mężczyzny: szeroką, swobodnie opadającą na ramiona muślinową kryzę układającą się w obfite fałdy, wams zapinany rzędem drobnych guzików i zawieszony na piersi łańcuch. Twórca medalierskiego portretu $\mathrm{z}$ dużą swobodą posłużył się zróżnicowanymi środkami artystycznego wyrazu, łącząc nieco głębszy modelunek partii twarzy i kryzy z łagodnie opracowanym wamsem. Na ramieniu portretowanego umieszczono datę 1594.

Medal upamiętnia Daniela Placotomusa, syna lekarza, aptekarza i pedagoga - Johanna Placotomusa, wł. Brettschneidera, pochodzącego z Münnerstadt we Frankonii (1514-1577) ${ }^{10}$. Brettschneiderowie przybyli do Gdańska z Królewca w 1550 r. Bezpośrednią przyczyną przyjazdu był konflikt Johanna, wykładowcy i rektora tamtejszego Uniwersytetu, $\mathrm{z}$ lekarzem księcia Albrechta Hohenzollerna, Aurifabrem. Już w 1553 r. Johann objął stanowisko kierownika gdańskiej apteki miejskiej, które piastował do 1577 r., z przerwą na lata 1555-1566, kiedy decyzją Rady zmuszony był opuścić miasto. Johann prowadził ożywioną działalność naukową ${ }^{11}$, opracowany przez niego system nauczania medycyny został przyjęty w Gdańsku jako obowiązujący. Mimo że nigdy nie udało mu się zrealizować planów objęcia katedry Gimnazjum Akademickiego ${ }^{12}$, edukację trzech swoich synów: Davida, Salomona i Abrahama, powierzył gdańskiej

9 Aukcja Sotheby's z 12 grudnia 2003 r., http://search.sothebys.com/jps/live/lot/Lot Detail.jsp?lot_id=45P6B [dostęp: 10.06.2005]. Model o średnicy $3,1 \mathrm{~cm}$ został wyceniony na 8 000-12 000 funtów, sprzedany za 9600 funtów (aukcja nr LO3233, obiekt nr 187). Za informację o pojawieniu się obiektu na rynku antykwarycznym dziękuję Panu prof. Marcinowi Kalecińskiemu.

10 Aleksander Drygaś, Placotomus (właść. Brettschneider) Jan [w:] Słownik biograficzny Pomorza Nadwiślańskiego, t. 2, red. Stanisław Gierszewski, Gdańsk 1992, s. 477-480 (pełna bibliografia tamże).

11 Opracował m.in. Pharmacopea in compendium redacta, dzieło wydane w $1560 \mathrm{r}$. w Antwerpii i później wielokrotnie wznawiane. W 1588 r. opublikował w Gdańsku broszurę zawierającą zalecenia dotyczące zachowania się w czasie zarazy, wypowiadał się również na temat teatru.

12 Drygaś, Placotomus..., s. 438. 
uczelni ${ }^{13}$. David (1565-1602) kontynuował naukę poza Gdańskiem, by w $1592 \mathrm{r}$. uzyskać doktorat z medycyny na Uniwersytecie w Padwie. Najstarszy z synów Johanna, Johann II (około 1547-1610), studiował w Rostocku, Fryburgu Bryzgowijskim, Królewcu i Bazylei ${ }^{14}$. Córka Anna (ur. 1574 r.) została żoną sekretarza Model do medalu Daniela miejskiego Kaspara Schütza.

Urodzony około $1566 \mathrm{r}^{15}$ Daniel był czwartym z pięciorga dzieci Johanna I i jego pierwszej żony Cathariny $(1525-1568)^{16}$. Studia, które rozpoczął w $1578 \mathrm{r}^{17}$, nie obejmowały, jak w wypadku starszych braci, nauki w Gimnazjum Akademickim. Na podstawie wpisu do sztambucha prawnika Davida Ulricha: Neminem sinunt leges nostrae in pauoertae viuere neque in aegestate morj. In suj memoriam scribebat haec Spirae 20 Septembris anno 86 D[omino] Dauidij Vlrico Daniel Placotomus Dantiscanus natione Borussus ${ }^{18}$, wiadomo, że w 1586 r. Daniel przebywał w Spirze. Jest on jedynym gdańszczaninem wśród autorów zamieszczonych tam wpisów z lat 1549-1577 oraz 1580-1614, sporządzonych przez prawników, teologów, przedstawicieli szlachty, urzędników oraz Lucasa Cranacha mł. Na uwagę zasługuje fakt, że w gronie przyjaciół właściciela albumu byli również profesor prawa, Martin Chemnitz m.. ${ }^{19}$, oraz profesor teologii w Wittenberdze, Johannes Bugenhagen ${ }^{20}$. Daniel jest także jedną spośród 87 osób, które wpisały się do sztambucha gdańskiego burmistrza Johanna Speymanna (1563-1625) w latach 1585-1588 w Genewie, Heidelbergu, Bazylei i Gdańsku (wśród nich znalazł się m.in. Arnold von Holten) ${ }^{21}$.

13 W księdze wpisów Gimnazjum Akademickiego znajdują się wpisy Davida (1581), Salomona (1581) i Abrahama (1581) oraz pozostałych członków rodziny Placotomusów: Jakoba (1582), Johanna (1618), Jakoba (1666), Abrahama (1681) i Abrahama Matthiasa (1718), por. Zbigniew Nowak, Przemysław Szafran, Księga wpisów Gimnazjum Akademickiego 1580-1814, Warszawa-Poznań 1974, s. 13, 22, 41, 52, 86-88.

14 Syn Johanna II, Jakob (ok. 1575-1620) był botanikiem i aptekarzem, założycielem ogrodu na tyłach Domu Opatów Pelplińskich oraz kierownikiem miejskiej apteki Rady. Aptekarzami zostali także wnuk Johanna II, Johann IV (1610-1664) i prawnuk Johann Georg (ok. 1644-1670), por. Dorothea Weichbrodt, Patrizier, Bürger, Einwohner der Freien und Hansestadt Danzig: in Stamm- und Namenstafeln vom 14.-18. Jahrhundert, Bd. 1, Klausdorf 1988, s. 371.

15 Podana przez Dorotheę Weichbrodt data - około $1558 \mathrm{r}$. - nie pokrywa się z datą wynikającą z inskrypcji umieszczonej w otoku omawianego medalu, por. ibidem.

16 W 1545 r. Johann Placotomus poślubił Catharinę z domu Rinck. W 1596 r. pojął za żonę Barbarę von Arlen, wdowę po rajcy Ambrosiusie Stormie, por. ibidem.

17 Ibidem.

18 Wittenberger Gelehrten Stammbuch. Das Stammbuch von Abraham und David Ulrich. Benutzt von 1549-1577 sowie 1580-1623. Herausgegeben durch das Deutschen Historischen Museum Berlin, bearbeitet von Wolfgang Klose, Halle 1999, s. 356. Łacińska sentencja odnosząca się do etosu zawodów prawniczych stanowi aluzję do profesji właściciela sztambucha. David Ulrich (ur. 1561), syn pastora Abrahama Ulricha, pierwszego właściciela albumu, był absolwentem uniwersytetów w Wittenberdze, Lipsku i Jenie.

19 Ibidem, s. 209.

$20 \quad$ Ibidem, s. 212.

21 Ketter Kunst Hamburg, http://www.kettererkunst.com/details-e.php?obnr=41090092 9\&anummer=359\&detail=1 Sale: 359 / Rare Books including Marine Art, Nov. 16./17. 2009 in Hamburg Lot 4 [dostęp: 2.10.2018]. 
Aleksandra Jaśniewicz
Do Daniela Placotomusa należał nadto sztambuch zmarłego w 1582 r. rektora elbląskiego Gimnazjum, Petrusa Himmelreicha, zawierający wpisy poczynione w Królewcu, Gdańsku i Lubece w latach 1564-157322.

W 1588 r. gdańszczanin został wpisany na listę studentów Uniwersytetu w Wittenberdze ${ }^{23}$. W dniu 29 maja 1616 r. Daniel Placotomus, stanu wolnego, został pochowany w kościele Najświętszej Marii Panny w Gdańsku²4.

Kamienny portret Placotomusa należy do niewielkiej grupy modeli, które posłużyły do wykonania medali upamiętniających gdańszczan. Obok omawianego obiektu są to, wspomniane wyżej, bukszpanowy model do medalu Dantyszka z 1529 r. przypisywany Weiditzowi, wykonany z tego samego materiału model do medalu kupca i przyszłego burmistrza Jorga Scheweke autorstwa Jacoba Bincka (1485-1568/1569) z 1544 r., opracowany w wapieniu z Solnhofen model do medalu Hansa Klura z 1546 r. autorstwa Hansa Schenka zw. Scheusslich (ok. 1500 - przed 1572) i kamienny model do medalu Jacoba Connerta, sporządzony zapewne w 1599 r. (Mistrz Jerzego Fryderyka Brandenburskiego [?]).

Modele, najczęściej woskowe, kamienne lub drewniane, niekiedy gipsowe, stiukowe, wykonane w łupku, alabastrze bądź glinie ${ }^{25}$, sporządzano w XV i XVI w., w okresie poprzedzającym upowszechnienie się techniki bicia medali stemplem. Większość zachowanych modeli pochodzi z XVI w., głównie z terenu Niemiec, gdzie wybierano do tego celu drewno i kamień. Wybór tworzywa determinował określone rozwiązania technologiczne związane z samym procesem odlewania, ale również możliwe do uzyskania walory artystyczne. Drewno pozwalało na uzyskanie subtelniejszego modelunku, struktura kamienia umożliwiała cięcie głębszego reliefu, a zarazem wnikliwe, bliskie sztuce złotniczej opracowanie szczegółu. Modele drewniane i kamienne wymagały rygorystycznego zdefiniowania formy już na wczesnym etapie prac. Łatwy w obróbce, gruboziarnisty wapień z Solnhofen, określany także mianem Marmelstein, był stosowany przede wszystkim w warsztatach norymberskich, podczas gdy drewno, głównie bukszpanowe - w augsburskich ${ }^{26}$. Podział ten jest jednak dość płynny, tym bardziej że niektórzy medalierzy, np. Joachim Deschler, pracowali w obu materiałach, w zależności od efektu, który chcieli uzyskać. Od lat sześćdziesiątych XVI stulecia na terenie Rzeszy zaczęła się upowszechniać preferowana przez Włochów technika woskowa, pozwalająca na dokonywanie poprawek

22 PAN Biblioteka Gdańska, Ms 2500; Maria Otto, Sztambuch Petrusa Himmelreicha [w:] W gdańskim ogrodzie muz. Gimnazjum Akademickie w Gdańsku wobec kultury starożytnych Greków i Rzymian, red. Maria Otto, Jan Pokrzywnicki, Pelplin 2016, s. 214, nr kat. 25. Kolejnym właścicielem albumu był sekretarz Rady Miejskiej, Herman Freder, który przekazał rękopis Bibliotece Rady. W sztambuchu nie ma wpisu Daniela Placotomusa. Za tę informację pragnę w tym miejscu serdecznie podziękować Pani dr Marii Otto z PAN Biblioteki Gdańskiej.

23 Wittenberger Gelehrten..., s. 356.

24 Weichbrodt, Patrizier, Bürger..., s. 371.

25 Wolfgang Steguweit, Europäische Medaillenkunst von der Renaissance bis zur Gegenwart, Berlin 1995, s. 42.

26 Ibidem, s. 44 
w dowolnej fazie pracy medaliera. Z końcem XVI w. stała się ona rozwiązaniem najchętniej wybieranym przez niemieckich medalierów.

Ze względu na rzadkość występowania i niepowtarzalność modele medalierskie stanowiły obiekt zainteresowania kolekcjonerów i jako okazy numizmatyczne chętnie prezentowane były w kunst-i wunderkamerach ${ }^{27}$. Malowane, inkrustowane drogimi kamieniami i oprawiane, bywały noszone na łańcuchu jako klejnoty ${ }^{28}$. Tym samym zacierała się pierwotna rola modeli, które stawały się autonomicznymi dziełami sztuki: drobnymi precjozami pokrewnymi kameom $^{29}$. Nie można zresztą wykluczyć, że wiele z owych obiektów określanych dziś mianem modeli nigdy nie zostało powielonych w metalu ${ }^{30}$.

Wybrane przez Daniela Placotomusa ujęcie profilowe należy do rzadziej reprezentowanych w medalach gdańszczan. Klasyczne ujęcie profilowe reprezentują dwa medale Dantyszka: wspomniany bukszpanowy model z 1529 r. i medal autorstwa Jana Secundusa, holenderskiego poety i humanisty z 1532 r., bukszpanowy model do medalu Georga Schewecke oraz dwa medale portretowe Marcusa Koehne-Jaschkego z lat 1561 i 1562, zamówione w augsburskim warsztacie Hansa Wilda.

Wśród wymienionych portretów brak jest bezpośredniej analogii do podobizny Placotomusa, która łączy profilowe ujęcie twarzy ze skrótowym przedstawieniem torsu, nawiązującym do szesnastowiecznego medalierstwa włoskiego. Ten typ portretu jest często spotykany np. w medalach czynnego w Augsburgu Friedricha Hagenauera (około 1499 - po 1546) oraz norymberczyka Matthesa Gebela (około 1500-1574).

27 Autor inwentarza kolekcji arcyksięcia Leopolda Wilhelma Austriackiego z 1659 r. wymienia dwa umieszczone w drewnianych ramach portrety medalionowe rzeźbione inn Cameo przez Joachima Deschlera oraz przypisywany temu artyście „ein rondes Contrafait des Albrecht Dürer in Busholcz geschnitten", zob. Eberhard Hempel, Deschler (Täschler, Teschler) Joachim [w:] Allgemeines Lexikon der bildenden Künstler, begründet von Ulrich Thieme, Felix Becker, Bd. 9 , Leipzig 1907-1950, s. 117.

28 Stugeweit, Europäische Medaillenkunst..., s. 43-44. Por. też Walter Cupperi, Beyond the notion of German medal. Some cases of transnational practice [w:] Wettstreit in Erz. Porträtmedaillen der deutschen Renaissance, hrsg. von Walter Cupperi, Martin Hirsch, Annette Kranz, Ulrich Pfisterer, Berlin 2013, s. 88, przyp. 13.

29 Powinowactwo pomiędzy kameami i medalami podkreśla m.in. Greene, Renaissance medals..., s. 70-76. W tym miejscu warto przytoczyć przykład Leone Leoniego (ok. 1509-1590), który tworzył zarówno medale, jak i kamee. W sporządzonym w 1549 r. medalu z portretem cesarza Karola V na awersie i wizerunkiem cesarzowej Izabeli na rewersie powtórzył on podobizny władców wykonane przez siebie w powstałej wcześniej onyksowej kamei z portretami Karola V i Filipa II na awersie oraz Izabeli na rewersie, por. Ernst Kris, Notes on Renaissance Cameos and Intaglios, „Metropolitan Museum Studies” 1930-1931, t. 3, nr 1, s. 10. Renesansowe kamee wykonywano najczęściej z sardonyksu, onyksu, agatu, ale także kryształu, muszli czy bursztynu, por. Anna Sobecka, Bursztyn bałtycki w kulturze [w:] Bursztyn bałtycki - skarb Zatoki Gdańskiej. Bursztyn bałtycki w nauce, kulturze, jubilerstwie i promocji regionu, red. Ryszard Sadziewski, Ryszard Pytlos, Jacek Szwedo, Gdańsk 2018, s. 76-93.

30 Cupperi, Beyond the notion..., s. 88, przyp. 13. 
Aleksandra Jaśniewicz
Fragmentaryczna wiedza na temat biografii syna gdańskiego lekarza utrudnia określenie okoliczności powstania medalu. Bliższych informacji w tej mierze nie ujawnia też zdawkowa inskrypcja. Zgodnie z praktyką medalierów niemieckich medal Placotomusa, tak jak i pozostałe szesnastowieczne medale osobiste gdańskich mieszczan, jest nośnikiem podstawowych informacji pozwalających na identyfikację osoby przedstawionej ${ }^{31}$ (na tym tle wyjątkową realizacją jest medal Hansa Klura, którego złożony program ideowy wpisuje się w ramy toczącego się dyskursu międzywyznaniowego).

Intrygującym szczegółem podobizny gdańszczanina jest głęboka szrama przecinająca kość policzkową i zniekształcająca ucho portretowanego. Wybór ujęcia eksponującego prawy profil nie pozostawia wątpliwości, że blizna stanowi ważny element wizerunku młodego mężczyzny. Niewykluczone, że prezentowana przez Placotomusa blizna, wyraźnie znacząca prawą część twarzy i ucho, stanowiła pamiątkę po pojedynku i była eksponowana przezeń jako stygmat bywałego w świecie człowieka honoru. Placotomus przebywał w latach osiemdziesiątych XVI w. na terenie Rzeszy niemieckiej: studiował w Wittenberdze, wcześniej w Spirze. Od około połowy XVI w. na niemieckich uczelniach wprowadzono zajęcia $\mathrm{z}$ fechtunku, początkowo po to, aby zachęcić do studiowania synów szlacheckich ${ }^{32}$. Pojedynkowanie, tradycyjnie zarezerwowane dla szlachty, stanowiło przejaw przyzwolenia dla konfrontacyjnych zachowań jej przedstawicieli i rozumiane było jako ekspresja arystokratycznej tożsamości. Upowszechniana wśród rzesz studentów znajomość reguł walki rapierem, była chętnie wcielana przez nich w praktykę, w związku z czym studenckie pojedynki były na porządku dziennym ${ }^{33}$. Fakt ten nie wpłynął na osłabienie elitarnych konotacji tego rodzaju potyczek, mających dowodzić odwagi i umiejętności podjęcia ryzyka oraz stawiania honoru ponad życie, a zatem cech i postaw tradycyjnie przypisywanych przedstawicielom najwyższych warstw społecznych ${ }^{34}$. Co więcej, ową zrytualizowaną formę przemocy zaczęto kojarzyć z wszechstronnym wykształceniem akademickim.

Medal Placotomusa jest nie tylko wyrazem potrzeby jednostkowego upamiętnienia, lecz także elementem szerszej strategii służącej budowaniu prestiżu rodu poprzez podobizny przedstawicieli kolejnych pokoleń.

Jako pierwsza uwieczniona została Catharina Placotomi, pierwsza żona Johanna Placotomusa ${ }^{35}$. Zleceniodawcą wykonanego pośmiertnie medalu, którego

${ }^{31}$ Rzadko na awersie pojawia się, jak w wypadku medalu Jacoba Schachmanna wykonanego w 1570 r. przez Severina Brachmanna, herb portretowanego, por. Rühle, Danziger Personenmedaillen..., s. 147, nr 10; Dutkowski, Motywy idei..., s. 232.

32 Elke Liermann, Mit Mantel und Degen. Studentisches Fechten im frühneuzeitlichen Freiburg/ Br. [w:] Frühneuzeitliche Universitätskulturen. Kulturhistorische Perspektiven auf die Hochschulen in Europa, hrsg. Barbara Krug-Richter, Ruth-E. Mohrmann, Köln-Weimar-Wien 2009, s. 43.

33 Ibidem.

34 David Quint, Duelling and Civility in Sixteenth Century Italy, „I Tatti Studies in the Italian Renaissance" 1997, vol. 7, s. 242-252.

35 Rühle, Danziger Personenmedaillen..., s. 147, nr 9; Stahr, Medalierstwo..., s. 157; Dutkowski, Motywy idei..., s. 232 (pełna literatura tamże). 
autorstwo wiąże się z osobą Joachima Deschlera (1500-1571), był owdowiały małżonek (il. 2). W pole niewielkiego (śr. $26 \mathrm{~mm}$ ), srebrnego medalu wpisano popiersiowy wizerunek Cathariny w ujęciu en trois quarts, odzianej w suknię $\mathrm{z}$ odcinanymi rękawami, $\mathrm{z}$ uniesionym kołnierzem, spod którego widoczna jest koszula wykończona niewielką kryzą. Okryta czepcem głowa niewiasty została Placotomusa... opracowana głębokim reliefem. W otoku umieszczono inskrypcję „CATARINA. D. [octoris] PLAC.[otomus] VXOR”. Po prawej stronie portretowanej, równolegle do napisu w otoku, wskazano wiek, którego dożyła portretowana: „AETAT.44”. Na rewersie widnieje informacja biograficzna „NASCITUR / ISLEBI IN / MANSFELD / ANNO 1.5.25 / MORITUR / DANTISCI / AO 68 / DECEMB DIE 12".

Te podstawowe informacje $\mathrm{z}$ życia Cathariny niemal całkowicie wyczerpują uchwytne wiadomości z życiorysu żony uczonego. Jedyny bliżej znany epizod z jej życia wiąże się z rolą, jaką odegrała w zatargu Placotomusa $\mathrm{z}$ Radą w sprawie pamfletu skierowanego przeciw biskupowi Hozjuszowi. Opublikowany w 1554 r. utwór, podpisany przez niejakiego Citopiusa, został uznany przez Radę Miejską za dzieło Johanna. W 1555 r. na mocy decyzji podjętej przez Radę Miejską uczonego uwięziono, a rok później zmuszono do opuszczenia miasto wraz $\mathrm{z}$ rodziną. Zanim wydano wyrok, w pertraktacje włączyła się Catharina, która wynegocjowała $\mathrm{z}$ Radą możliwość pozostania rodziny w mieście pod warunkiem konwersji oskarżonego na katolicyzm. Johann odrzucił takie rozwiązanie konfliktu i rodzina zmuszona była uchodzić z Gdańska. W 1558 r. Placotomus powrócił do miasta. W 1566 r. ponownie objął

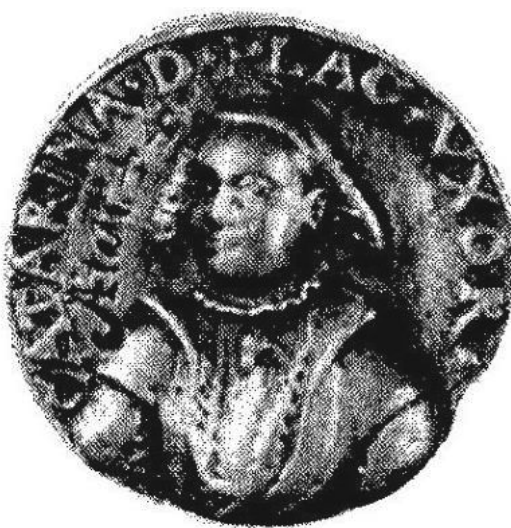

Il. 2. Joachim Deschler (?), medal Cathariny Placotomi, 1568, zaginiony, repr. za: Rühle 1930, il. 9 stanowisko kierownika apteki radzieckiej.

Podobizna żony gdańskiego farmaceuty, będąca jedynym wizerunkiem kobiecym wśród szesnastowiecznych medali upamiętniających mieszkańców Gdańska, jest - jak zauważył Jarosław Dutkowski - wzorowana na portrecie Kathariny von Bora autorstwa Lucasa Cranacha st. ${ }^{36}$ Formuła portretu wybrana przez zamawiającego, gorliwego luteranina pozostającego w bliskim kontakcie z Filipem Melanchtonem ${ }^{37}$, ukazuje zatem Catharinę jako uosobienie ideału ewangelickiej małżonki. Przymiotami czyniącymi z Kathariny von Bora przykład do naśladowania były chwalone przez Lutra w roku zawarcia małżeństwa zgodność i posłuszeństwo we wszystkim ${ }^{38}$. W pierwszych latach wspólnego

Ibidem, s. 232

37 Drygaś, Placotomus, s. 437.

38 Roland H. Bainton, Frauen der Reformation. Von Katharina von Bora bis Anna Zwingli. 10 Porträts, aus dem Englischen übersetzt und bearbeitet von Marion Obitz, Gütersloh 1995, s. 20. 
Aleksandra życia reformator doceniał także pracowitość i wsparcie ze strony Kathariny ${ }^{39}$, Jaśniewicz która zajmowała się nie tylko prowadzeniem domu, lecz także włączała się w dysputy teologiczne i doradzała mężowi ${ }^{40}$.

W świetle informacji o negocjacjach prowadzonych przez Catharinę z gdańską Radą można wnioskować o jej odwadze i gotowości do obrony męża. Natomiast wynik pertraktacji pozostawał nie do zaakceptowania, a warunek konwersji, na jaki przystała, mógł budzić zastrzeżenia co do jej prawowierności. Medal odlany w roku śmierci Cathariny rozwiewa tego rodzaju wątpliwości. Utrwala jej wizerunek jako przykładnej luteranki uosabiającej cnoty niewieście, oddanej małżonki, która z poświęceniem wspierała swojego męża. Jednocześnie portret ten, tak jak i podobizna Kathariny von Bora, kieruje myśl właśnie ku osobie wybitnego małżonka, w tym wypadku fundatora medalu.

On sam został uwieczniony przez anonimowego miedziorytnika w $1574 \mathrm{r}$. (il. 3). Pozbawiony znamion idealizacji portret nestora rodu stojącego za pulpitem został opatrzony inskrypcja „ANNO · DOMINI $\cdot 1 \cdot 5 \cdot 7 \cdot 4 \cdot / \cdot$ ANNO $\cdot$ ÆTATIS - CIRCITER ·60 / ·IMAGO - IOHANNIS · PLACOTOMI - MEDICINÆ ·

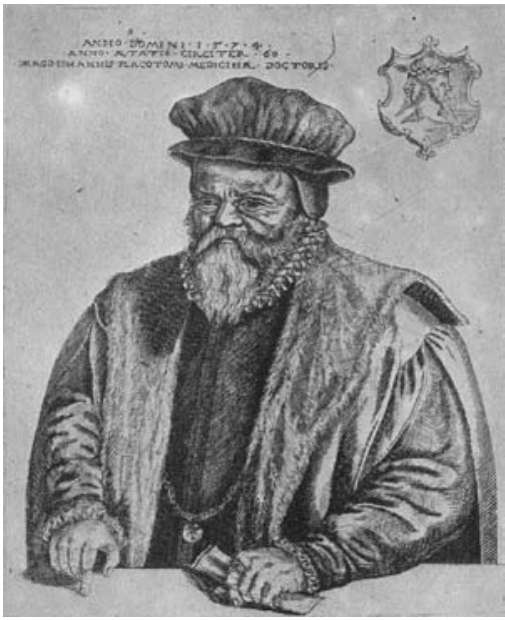

Il. 3. Rytownik nieznany, portret Johanna I Placotomusa, 1574, PAN Biblioteka Gdańska, fot. PAN Biblioteka Gdańska DOCTORIS”. I w tym portrecie zwrócono uwagę na podkreślenie wiary portretowanego. Uczyniono to za pomocą zawieszonego na piersi medalionu $\mathrm{z}$ wizerunkiem Ukrzyżowanego Chrystusa, będącego deklaracją luteranizmu lekarza ${ }^{41}$. Dostatnie odzienie uczonego: czepiec, szuba, wykończony kryzą wams i łańcuch, potwierdza zawodowy sukces. Stanowcze spojrzenie podkreślone ściągniętymi brwiami i zdecydowany gest prawej dłoni z palcem wskazującym skierowanym w dół, w stronę pulpitu, sugerują stanowczość lekarza. Odczytany w duchu tradycji retorycznej gest prawej ręki służy podkreśleniu doniosłości przekazywanego komunikatu ${ }^{42}$. Ten zaś został zogniskowany, jak zauważa Krystyna Jackowska, na cnocie przezorności, Prudentii, sygnalizowanej poprzez wyobrażenie Janusa Bifronsa umieszczone w kartuszu w prawej górnej partii kompozycji ${ }^{43}$. Znaczenie roztropności i odpowiedzialności zawodowej

\footnotetext{
39 Gerhard Markert, Menschen um Luther. Eine Geschichte der Reformation in Lebensbilder, Ostfildern 2008, s. 204.

${ }^{40} \quad$ Ibidem. Luter podkreślał także jej silny charakter, ta cecha charakteru nie była wszakże przedmiotem pochwał ze strony reformatora, który w późniejszych latach określał przedsiębiorczą Katharinę przydomkiem „mein Herr”; Bainton, Frauen der Reformation..., s. 22.

${ }^{41}$ Krystyna Jackowska, Adam Szarszewski, Piotr Paluchowski, Portrety gdańskich lekarzy (XVI-XVIII w.), Gdańsk 2015, s. 44 (wcześniejsza literatura tamże).

42 Ibidem.

43 Ibidem.
} 
jako podstawy pracy lekarza i farmaceuty Placotomus podkreślał szczególnie w swym dziele Pharmacopoea in compendium redacta (1560).

Około połowy XVII w. powstał srebrny medal wnuka Johanna (bratanka Daniela), Johanna IV $(1610-1664 \text {, il. 4) })^{44}$. Owalny, niesygnowany medal opatrzony inskrypcją "JOHANN PLACOTOMUS" w otoku oraz „Natus 1610” po lewej stronie, na wysokości twarzy portretowanego, przedstawia popiersie mężczyzny o modelowanym ze szwedzka zaroście, odzianego $\mathrm{w}$ wams $\mathrm{z}$ płaskim kołnierzem. Jego wyrazista fizjonomia o nieregularnych rysach i blisko osadzonych oczach zwraca uwage podobieństwem do twarzy Johanna I, który został utrwalony w miedziorycie z 1574 r. Być może wspólne cechy wyglądu zostały podkreślone intencjonalnie, bo to właśnie wnuk Johanna kontynuo-

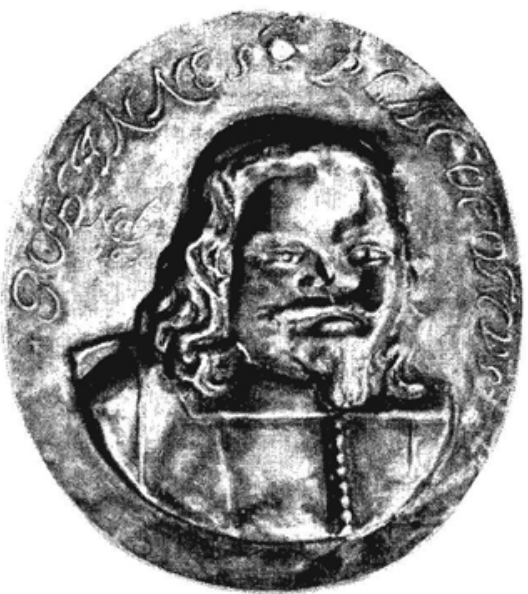

Il. 4. Medalier nieznany, medal Johanna IV Placotomusa, poł. XVII w., zaginiony, repr. za: Rühle 1930, il. 12 wał tradycje rodzinne. Pracując jako aptekarz przy Łagiewnikach na gdańskim Starym Mieście, zdobył uznanie po opublikowaniu Liber memorandorum Pharmacopäeorum.

Obfitość portretów przedstawicieli gdańskiej rodziny Placotomusów ustępuje liczbą jedynie podobiznom członków kupieckiego rodu Connertów, którzy zostali uwiecznieni na medalach - wspomniane wyżej srebrne medale Johanna I (1556) i Johanna IV (1557) Connertów; kamienny model do medalu Jacoba Connerta (1599), w rzeźbie monumentalnej - portret rajcy Johanna III Connerta (1550) umieszczony w fasadzie sierocińca przy kościele św. Elżbiety ${ }^{45}$, oraz w malarstwie - epitafium rodziny Connertów w kościele Najświętszej Marii Panny z lat 1554-1556 z portretami rajcy Johanna III Connerta, jego żony Gertrude, trzech córek oraz siedmiu synów; epitafium Anny Loitz-Connertowej z lat 1563-1564 z portretami Anny (zm. 1563), jej męża Hansa IV Connerta, ich syna i dwóch córek.

W ostatnim $\mathrm{z}$ wymienionych dzieł Anna z domu Loitz została ukazana w patrycjuszowskim stroju, który zdobią dwa złote łańcuchy - na dłuższym z nich zawieszono medal (il. 5). Niestety, ów niewielki obiekt pozbawiony jest detali pozwalających na identyfikację przedstawienia zdobiącego awers. Rozpoznanie szczegółów dekoracji zdobiących medale jest natomiast możliwe w epitafium Schadiusów z 1588 r. (il. 6). Medal noszony przez żonę Johanna Schadiusa jest ozdobiony motywem krzyża, $z$ kolei ten eksponowany na piersi gdańskiego lekarza zawiera podwójny profilowy portret zwróconych ku sobie

44 Rühle, Danziger Personenmedaillen..., s. 148, nr 12.

45 Janusz Pałubicki, Rzeźba kamienna w Gdańsku w latach 1517-1585, „Gdańskie Studia Muzealne” 1981, t. 3, s. 182, 183; Katarzyna Cieślak, Kościół - cmentarzem. Sztuka nagrobna w Gdańsku (XV-XVII w). „Długie trwanie” epitafium, Gdańsk 1992, s. 43. 


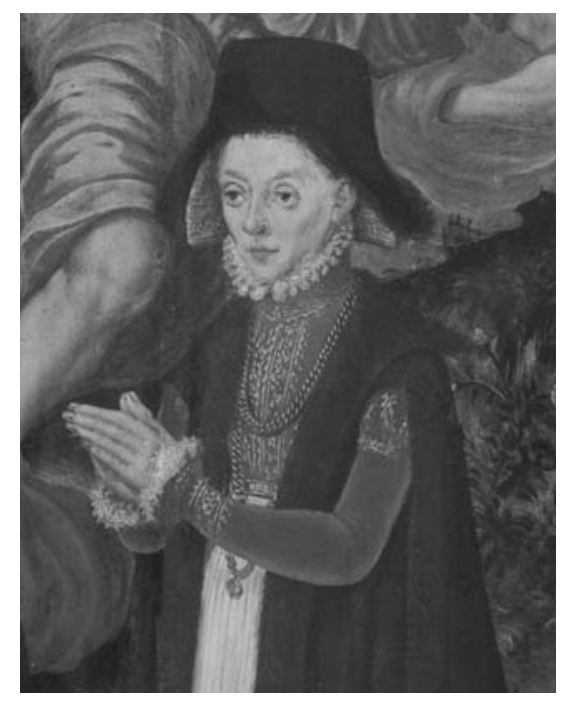

Il. 5. Malarz nieznany, epitafium Anny Loitz-Connertowej, fragment, 1563-1564, kościół Najświętszej Marii Panny w Gdańsku, fot. Dariusz Kula postaci, noszacych stroje ozdobione kryzami. Niewykluczone, że medal ten, reprezentujący typ nieobecny w udokumentowanym materiale zabytkowym, prezentuje podobizny uwiecznionych na obrazie małżonków i pełni tu funkcję swoistego portretu w portrecie.

Medale osobiste gdańszczan stanowią fenomen specyficznie szesnastowieczny. Analogicznie do zamawianych poza Gdańskiem portretów malarskich $\mathrm{z}$ lat 1507-1543 odzwierciedlają one potrzebę upamiętnienia, dokumentacji historii rodu i potwierdzenia społecznego sukcesu, stanowiąc zarazem ważny impuls dla miejscowego środowiska artystycznego.

W kolejnym stuleciu medale omawianego typu stanowią ułamek lokalnej produkcji medalierskiej. W XVII w. chętniej - niż podobizny członków rodziny - eksponowano oficjalne Gnademedaillen (medale łaskawości), jak w rzeźbionych portretach nadwornego lekarza, Johanna Posseliusa (epitafium w kościele św. Mikołaja, przed 1625) i szefa komisji okrętowej Gabriela Posse (Muzeum Narodowe w Gdańsku, 1632), w których portretowani noszą medale z wizerunkiem Zygmunta III Wazy ${ }^{46}$.

Zainteresowanie medalami osobistymi nie wygasło jednak całkowicie. Powstały wówczas trzy medale Aegidiusa Straucha (Johann Höhn mł. [?] jeden medal z 1675 r. i dwa z 1678 r.) oraz dwa pośmiertnie wybite medale Jana Heweliusza (Johann Höhn ml, 1687; Arvid Karsten, 1688), będące formą uhonorowania ważnych postaci w publicznym życiu Gdańska. Tradycji szesnastowiecznych medali służących prywatnej komemoracji mieszkańców miasta bliższy jest w wymiarze funkcjonalnym medal Christiny Uphagen (1689), który powstał jako wizualny argument na rzecz oczyszczenia dobrego imienia patrycjuszki ${ }^{47}$, oraz medale Johanna IV Placotomusa i Ludwiga Schewecke (1694), oba nawiązujące do medalierskich portretów przodków. Na rewersie medalu Schewecke widnieją

46 Medale są obecne w malowanych przez Andreasa Stecha podobiznach Johanna Gabriela Schmiedta (Muzeum Narodowe w Gdańsku, 1675) oraz Młodzieńca z medalem (Muzeum Narodowe w Gdańsku, 1680), por. Aleksandra Jaśniewicz, Portret w Gdańsku od schyłku średniowiecza do późnego baroku (1420-1700). Malarstwo, rysunek, Gdańsk 2018, s. 97, 173, 471, 473, nr kat. S.54, S.56 (wcześniejsza literatura tamże). Pozbawione czytelnych szczegółów medale to akcesoria służące aluzyjnemu podkreśleniu rangi portretowanych. Pozwalają domyślać się wysokiego urodzenia osób je prezentujących, ich koneksji bądź elitarnych zainteresowań.

47 Maria Stahr, Johann Höhn mł. (Gdańsk 1642-1693), przypisywany, Christina Pauli z Uphagenów (1633-1689), medal, 1689 [w:] Aurea Porta Rzeczypospolitej. Sztuka gdańska od połowy XV do końca XVIII wieku, t. 2, Katalog, Gdańsk 1997, s. 197, nr kat. V.85. 


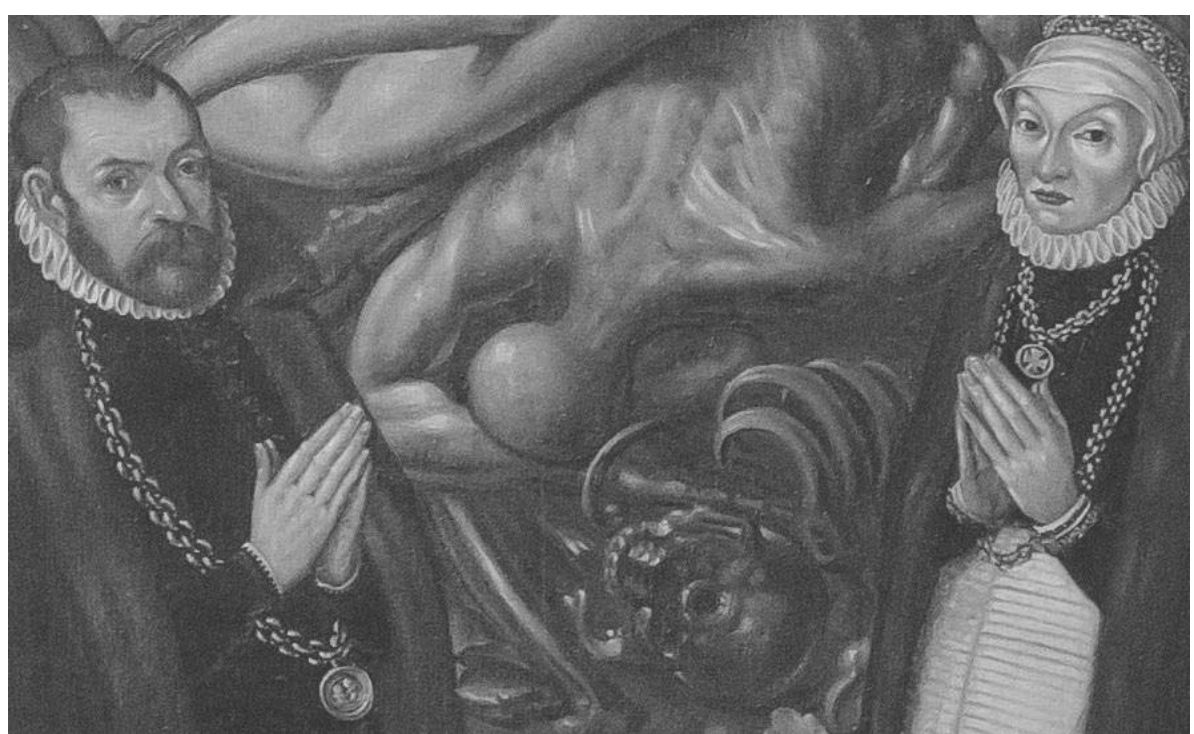

Model

do medalu

Daniela

Placotomusa...

Il. 6. Malarz nieznany, epitafium Jacoba Schadiusa, fragment, 1588, kościół Najświętszej Marii Panny w Gdańsku, fot. Dariusz Kula

imię i tarcza herbowa, w awersie wykorzystano natomiast podobiznę protoplasty rodu, Jorga Schewecke, znaną z bukszpanowego modelu do medalu z 1544 r. Medal Ludwiga Schewecke zamyka historię gdańskich medali osobistych.

\section{Bibliografia}

Bainton Roland H., Obitz Marion, Frauen der Reformation. Von Katharina von Bora bis Anna Zwingli. 10 Porträts, Gütersloh 1995.

Börner Lore, Deutsche Medaillenkleinode des 16. und 17. Jahrhunderts, Leipzig 1981.

Cieślak Katarzyna, Kościót - cmentarzem. Sztuka nagrobna w Gdańsku (XV-XVII w). „Dlugie trwanie" epitafium, Gdańsk 1992.

Cupperi Walter, Beyond the notion of German medal. Some cases of transnational practice [w:] Wettstreit in Erz. Porträtmedaillen der deutschen Renaissance, hrsg. von Walter Cupper, Mallin Hirsch, Anette Kranz, Ulrich Pfisterer, Berlin 2013, s. 81-89.

Drygaś Aleksander, Placotomus (właść. Brettschneider) Jan [w:] Słownik biograficzny Pomorza Nadwiślańskiego, t. 2, red. Stanisław Gierszewski, Gdańsk 1992, s. 477-480.

Dutkowski Jarosław, Motywy idei mieszczańskich na monetach, medalach i żetonach gdańskich od końca XVI do połowy XVIII wieku w Gdańsku, praca doktorska napisana na UG pod kierunkiem prof. dr hab. Krzysztofa M. Kowalskiego, Gdańsk 2007.

Greene Thomas W., Renaissance medals in relation to antique gems and coins, „The Numismatic Chronicle and Journal of the Numismatic Society" 1885, vol. 5, s. 73. Habich Georg, Die Deutschen Schaumünzen des XVI Jahrhunderts, München 1924-1932. 
Aleksandra Jaśniewicz
Jackowska Krystyna, Szarszewski Adam, Paluchowski Piotr, Portrety gdańskich lekarzy (XVI-XVIII w.), Gdańsk 2015.

Liermann Elke, Studentische Fechten im frühneuzeitlichen Freiburg / Br. [w:] Frühneuzeitlische Universitätskulturen. Kulturgeschichte Perspektiven auf die Hochschule in Europa, hrsg. Barbara Krug-Richter, Ruth E. Mohrmann, Köln-Weimar-Wien 2009, s. 31-40.

Morka Mieczysław, The beginnings of Medallic Art in Poland during the Times of Zygmunt I and Bona Sforza, „Atribus et Historiae” 2008, vol. 29, No. 58, s. 65-87.

Nowak Zbigniew, Szafran Przemysław, Księga wpisów Gimnazjum Akademickiego 1580-1814, Warszawa-Poznań 1974.

Nowaliński Karol, Medalierstwo gdańskie XVI-XVIII wieku, „Przegląd numizmatyczny” 1997, t. 4, nr 19, s. 6-13.

Otto Maria, Sztambuch Petrusa Himmerleicha [w:] W gdańskim ogrodzie muz. Gimnazjum Akademickie w Gdańsku wobec kultury starożytnych Greków i Rzymian, red. Maria Otto, Jan Pokrzywnicki, Pelplin 2016, s. 214.

Pałubicki Janusz, Rzeźba kamienna w Gdańsku w latach 1517-1585, „Gdańskie Studia Muzealne" 1981, t. 3, s. 175-196, 391-412.

Quint David, Duelling and Civility in Sixteenth Century Italy, „I Tatti Studies in the Italian Renaissance" 1997, vol. 7, s. 242-252.

Rühle Siegfried, Die Danziger Personenmedaillen, „Zeitschrift des Westpreussischen Geschichtsvereins" 1930, Bd. 70, s. 141-175.

Scher Stephen K., Introduction [w:] The currency of fame. Portrait Medals of the Renaissance, ed. Stephen K. Scher, New York 1994, s. 13-16.

Sobecka Anna, Bursztyn baltycki w kulturze [w:] Bursztyn battycki - skarb Zatoki Gdańskiej. Bursztyn battycki w nauce, kulturze, jubilerstwie i promocji regionu, red. Ryszard Sadziewski, Ryszard Pytlos, Jacek Szwedo, Gdańsk 2018, s. 76-93.

Sobecka Anna, Malarstwo nowożytne w kościele Mariackim w Gdańsku [w:] Kościół Mariacki w Gdańsku, red. J. Friedrich, t. 2. Wyposażenie, Gdańsk 2019, s. 138-167.

Stahr Maria, Medalierstwo [w:] Aurea Porta Rzeczypospolitej. Sztuka gdańska od połowy XV do końca XVII wieku, t. 1, Eseje, red. Teresa Grzybkowska, Gdańsk 1997, s. $157-169$.

Steguweit Wolfgang, Europäische Medaillenkunst von der Renaissance bis zur Gegenwart, Berlin 1999.

Weichbrodt Dorothea, Patrizier, Bürger, Einwohner der Freien und Hansestadt Danzig: in Stamm- und Namentafeln vom 14.-18. Jahrhundert, Bd. 1, Klausdorf 1988, s. 371.

Więcek Adam, Dzieje sztuki medalierskiej w Polsce, Kraków 1989.

Wittenberger Gelehrten Stammbuch. Das Stammbuch von Abraham und David Ulrich. Benutzt von 1549-1577 sowie 1580-1623. Herausgegeben durch das Deutschen Historischen Museum Berlin, bearbeitet von Wolfgang Klose, Halle 1999. 
Stone Model for the Medal of Daniel Placotomus in the Context of $16^{\text {th }}$ century Personal Medals in Gdańsk

Personal medals, originated in $15^{\text {th }}$ century Italy, became popular in Gdańsk in the course of the following century. Already in 1522-1532, Jan Dantyszek was commemorated in five medals. In 1544-1599, seven medals and two medallic models were commisioned for the residents of the city: Jorg Schewecke, Johann, Hans and Jacob Connert, Marcus Koehne-Jaschke, Catharina Placotomi, Jacob Schachmann and Hans Schwarzwaldt.

The current article is focused on the hitherto unknown model for the medal of Daniel Placotomus (c. 1566-1616). Carved in Solnhofen sandstone in 1594, it commemorates the fourth child of Johann Placotomus (1514-1577), a distinguished medic, pharmacist, and pedagogue active in Gdańsk from 1550. The study presents a reconstruction of the biography of Daniel Placotomus, a relatively little known member of the Placotomus family and seeks to establish motivation behind the commission of his likeness. The sandstone portrait is analysed in the context of the $16^{\text {th }}$ century medallic portraits of Gdańsk residents and in relation to the remaining portraits of the members of the Placotomus family.
Model

do medalu

Daniela

Placotomusa... 